\title{
Ovaries of Puto superbus and Ceroputo pilosellae (Hemiptera: Coccoidea): Morphology, ultrastructure, phylogenetic and taxonomic implications
}

\author{
Anna MiCHALIK ${ }^{1}$, MaŁgorzata KALANDYK-KOŁODZIEJCZYK², Ewa SIMON², Michą KOBIAŁKA ${ }^{1}$ \\ and TERESA SZKLARZEWICZ ${ }^{1}$ \\ ${ }^{1}$ Department of Developmental Biology and Morphology of Invertebrates, Institute of Zoology, Jagiellonian University, \\ Gronostajowa 9, 30-387 Kraków, Poland; e-mail: a.michalik@uj.edu.pl \\ ${ }^{2}$ Department of Zoology, Faculty of Biology and Environmental Protection, University of Silesia, Bankowa 9, 40-007 Katowice, \\ Poland
}

Key words. Hemiptera, Coccoidea, Puto superbus, Ceroputo pilosellae, ovariole, germ cells, trophocyte, oocyte, scale insects

\begin{abstract}
Ovaries of Puto superbus and Ceroputo pilosellae are composed of numerous short telotrophic ovarioles that are arranged around the distal part of the lateral oviduct. An individual ovariole consists of a distal trophic chamber (= tropharium) and proximal vitellarium. The tropharia enclose individual trophocytes (= nurse cells) and early previtellogenic oocytes termed arrested oocytes. A single oocyte develops in each vitellarium. Analysis of serial sections has shown that ovarioles of $P$. superbus contain from 16 to 51 germ cells (13-43 trophocytes, 2-7 arrested oocytes, 1 developing oocyte) while those of $C$. pilosellae from only 8 to 10 germ cells (5-7 trophocytes, $0-2$ arrested oocytes, 1 developing oocyte). The classification and phylogeny of scale insects are discussed taking into consideration the results of this study.
\end{abstract}

\section{INTRODUCTION}

Scale insects (coccoids) are classified as the superfamily Coccoidea in the suborder Sternorrhyncha within the order Hemiptera. The Coccoidea superfamily contains nearly 8000 species worldwide (Gullan \& Martin, 2009).

Informally coccoids are subdivided into two groups: Archaeococcoidea (archaeococcoids or archaeococcids) with about 700 species and Neococcoidea (neococcoids or neococcids) with over 7000 species (see e.g. Borchsenius, 1958; Cook et al., 2002; Gullan \& Cook, 2007; Kondo et al., 2008; Gullan \& Martin, 2009 for further details). In spite of numerous earlier morphological and even most recent molecular studies, the classification of the Archaeococcoidea remains a matter of debate. Archaeococcoids have many plesiomorphic features (XX-XO sex chromosome system, abdominal spiracles and generally compound eyes in males). Thus, their monophyletic origin is not evident. In contrast to the archaeococcoids, neococcoids are a monophyletic group, characterized by derived features (e.g. paternal genome elimination and absence of abdominal spiracles) (Koteja, 1974, 1996; Foldi, 1997; Cook et al., 2002; Gullan \& Cook, 2007, Gullan \& Martin, 2009). There are, however, numerous structures that indicate the rich diversity and intermediate states of these two groups (Koteja 2000, 2004, 2008; Koteja \& Poinar, 2001; Koteja \& Azar, 2008).

One of the important taxonomical problems concerning the Coccoidea is the position of the genus Puto Signoret, 1875. Puto superbus was originally described by Leonardi (1907) as Macrocerococcus superbus. This species was assigned to different genera by many authors: to Ceroputo Šulc, 1898 (e.g. Lindinger, 1912), to Mac- rocerococcus Leonardi, 1907 (e.g. Borchsenius, 1949; Koteja, 1974) and more recently to Puto (e.g. Tereznikova, 1975; Marotta \& Tranfaglia, 1993; Kosztarab \& Kozár, 1988; Williams et al., 2011). Genus Puto was considered to belong to Pseudococcidae (e.g. Koteja, 1974; Danzig, 1986, 1999; Kosztarab \& Kozár, 1988) or Putoidae (Beardsley, 1969; Cook et al., 2002; Gullan \& Cook, 2007; Gullan \& Martin, 2009; Kondo et al., 2008, Williams et al., 2011). The family Putoidae was placed with either the archaeococcoids (Gullan \& Cook, 2007; Gullan \& Martin, 2009; Kondo et al., 2008) or neococcoids (Koteja \& Azar, 2008). Gavrilov-Zimin \& Danzig (2012) did not accept the concept presented by Williams et al. (2011) and placed Puto within the family Pseudococcidae.

The genus Ceroputo that was synonymized with the genus Puto (Ferris, 1918) was resurrected by Hardy at al. (2008) and is now considered to be one of the genera of the Pseudococcidae placed in the subfamily Phenacoccinae.

As in all hemipterans, ovaries of scale insects, are composed of ovarioles of telotrophic type (for classification and organization of insect ovaries see Biliński, 1998; Büning, 1994). An individual ovariole of hemipterans consists of a terminal filament, trophic chamber (tropharium), vitellarium and ovariolar stalk (pedicel). The latter element joins the ovariole to the lateral oviduct. The tropharium encloses trophocytes (nurse cells) and early meiotic oocytes (termed arrested oocytes). Linearly arranged developing oocytes are present in the vitellarium. Numerous extensive studies on the ovaries of representatives of various hemipteran suborders (i.e. aphids, scale insects, psyllids, whiteflies, cicadomorphans, fulgoromor- 
phans and heteropterans), have shown that in spite of numerous morphological differences between them they share several synapomorphic characters: (1) in each ovariole only a single cluster of germ cells (oocytes and trophocytes) is present, (2) in each cluster more than one oocyte develops and (3) the centre of the tropharium is occupied by a common cytoplasmic area filled with microtubules, termed a trophic core (e.g. Büning, 1985; Książkiewicz-Kapralska, 1985; Huebner, 1981; Biliński et al., 1990; Simiczyjew et al., 1998; Szklarzewicz, 1998a; Štys et al., 1998; Szklarzewicz et al., 2000, 2009). In contrast to the ovarioles of other hemipterans, the ovarioles of scale insects do not possess terminal filaments and contain a small number of germ cells in each ovariole and single oocyte in the vitellarium (scale insect synapomorphies) (Książkiewicz, 1980; Szklarzewicz \& Biliński, 1995; Szklarzewicz, 1997, 1998a, b, c; Koteja et al., 2003; Szklarzewicz et al., 2002, 2005, 2010, 2013; Niżnik \& Szklarzewicz, 2007). It is noteworthy that their ovaries appeared to be so different from those of other hemipterans that they were formerly classified as polytrophic (Jura, 1958; Magakyan et al., 1975). Szklarzewicz and co-workers in a series of papers have shown that the ovaries of archaeococcoids exhibit significant differences in their organization from those of neococcoids (Szklarzewicz \& Biliński, 1995; Szklarzewicz, 1997, 1998a, b, c; Szklarzewicz et al., 2002, 2005, 2010, 2013; Koteja et al., 2003; Niżnik \& Szklarzewicz, 2007). First, the ovarioles of archaeococcoids contain a greater number of germ cells (trophocytes + oocytes) than those of neococcoids. Second, tropharia of archaeococcoids contain trophocytes and arrested oocytes (except for members of the family Monophlebidae), whereas those of neococcoids contain only trophocytes (except for members of the families Kermesidae and some representatives of Eriococcidae). Moreover, the arrested oocytes of archaeococcoids may develop, whereas those of neococcoids are not capable of further development. As a consequence, in each ovariole of a neococcoid scale insect a single egg is produced. Based on these observations, Szklarzewicz (1998a) postulated that: (1) during the evolution of scale insects there was a gradual reduction in germ cell number per ovariole and (2) the organization of the ovaries of archaeococcoids is more similar to those of aphids (i.e. a sister group of scale insects) than neococcoids. This all indicates that studies on ovaries may be useful for determining phylogenetic relationships. Therefore the aims of this study were to: (1) describe the organization of the ovaries in Puto superbus and Ceroputo pilosellae, (2) verify the taxonomic placement of both these species and (3) provide further information about the phylogeny of scale insects and anagenesis of their ovaries.

\section{MATERIAL AND METHODS}

\section{Insects}

The ovaries of Ceroputo pilosellae Šulc, 1898 and Puto superbus Leonardi, 1907 were examined using ultrastructural, histological and histochemical methods.

Adult females of Ceroputo pilosellae were collected from leaves of the mouse-ear hawkweed, Hieracium pilosella near
Będzin (Southern Poland) in April. Adult females of Puto superbus were collected from the grass, Arrhenatherum elatius in Katowice (Southern Poland) and near Wolsztyn (Western Poland) in June.

\section{Light and transmission electron microscopy}

The dissected ovaries were fixed in $2.5 \%$ glutaraldehyde in 0.1 phosphate buffer ( $\mathrm{pH} 7.4$ ) for 3 months. The material was then rinsed in the same buffer with the addition of sucrose (5.8 $\mathrm{g} / 100 \mathrm{ml}$ ) and postfixed for $1.5 \mathrm{~h}$ in $1 \%$ osmium tetroxide and dehydrated in a graded series of ethanol and acetone. The material was next embedded in epoxy resin Epon 812 (Serva, Heidelberg, Germany). Semithin sections ( $1 \mu \mathrm{m}$ thick) were stained with $1 \%$ methylene blue in $1 \%$ borax and photographed with the aid of Nikon Eclipse 80i and Leica DMR microscopes. Ultrathin sections (90 nm thick) were contrasted with uranyl acetate and lead citrate and examined under a JEOL JEM 100SX electron microscope at $80 \mathrm{kV}$.

\section{Fluorescence microscopy}

The dissected ovaries were fixed in $4 \%$ formaldehyde in phosphate buffered saline (PBS) for $45 \mathrm{~min}$ at room temperature. The material was next rinsed in the same buffer and stained in a mixture of rhodamine-labeled phalloidin $(2 \mu \mathrm{g} / \mathrm{ml})$ and DAPI $(12 \mu \mathrm{g} / \mathrm{ml})$ for $90 \mathrm{~min}$ in complete darkness. Stained ovaries were examined using an Axiovert 200M confocal microscope.

\section{RESULTS}

\section{Gross morphology of the ovaries of Puto superbus and Ceroputo pilosellae}

The ovaries of Puto superbus and Ceroputo pilosellae are composed of numerous (about 200) short telotrophic ovarioles in various stages of development (Fig. 1A). The ovarioles protrude radially from along two thirds of the length of the lateral oviduct (Fig. 1A). They are connected with the lateral oviduct by very short ovariolar stalks (Fig. 1A).

\section{Structure of an ovariole}

The ovarioles studied are devoid of terminal filaments (Fig. 1A). An individual ovariole consists of a distal tropharium and a proximal vitellarium (Fig. 1A-D, H). A single oocyte develops in each vitellarium (Fig. 1A, H). All germ cells (trophocytes and oocytes) in an ovariole are interconnected and belong to one cluster. The analysis of serial sections of 10 ovarioles of each species has shown that the total number of germ cells per ovariole is not constant and ranges from 8 to 10 in $C$. pilosellae and from 16 to 51 in P. superbus (see Table 1). As a rule, the clusters in $C$. pilosellae were composed of 8 germ cells. Only one ovariole contained 10 germ cells. The largest cluster recorded in $P$. superbus was composed of 51 germ cells and the smallest 16 germ cells. The number of germ cells recorded in the 10 ovarioles of $C$. pilosellae and $P$. superbus analyzed is shown in Table 1.

In both species the tropharia are surrounded by a single layer of flattened cells that form an inner epithelial sheath (Fig. 1A, C, D, H). The tropharia contain individual trophocytes (Fig. 1A, B, D, H) and arrested oocytes (Fig. $1 \mathrm{~A}, \mathrm{C}, \mathrm{D})$. The latter are localized in the proximal region of the tropharium (Fig. 1C, D). Analysis of serial sections of 10 ovarioles of $C$. pilosellae revealed that the tropharia 
contained from 5 to 7 trophocytes and 1 or 2 arrested oocytes. Arrested oocytes were only recorded in one ovariole. In tropharia of $P$. superbus there were from 13 to 43 trophocytes and from 2 to 7 arrested oocytes. The centre of the tropharium is occupied by a cytoplasmic area termed a trophic core (Fig. 1A, B, D, H), which is connected with both trophocytes and oocytes. Trophocytes communicate with the trophic core by means of cytoplasmic processes (Fig. 1B, D, H) and oocytes by means of nutritive cords (Fig. 1B, D). Both processes of trophocytes and nutritive cords contain numerous microtubules (not shown). Fluorescent labeling with rhodamine-phalloidin has revealed that there are numerous microfilaments in the trophic core (Fig. 1H). In addition to these cytoskeletal elements there are numerous microtubules in this region (Fig. 1E). Trophocytes are large and cone-shaped (Fig. 1A, B, D, H). They are characterized by giant, lobated nuclei (Fig. 1A-D, F, H) containing several prominent nucleoli (Fig. 1A-D). Trophocyte nuclei stain intensely with DAPI (Fig. 1H). Trophocyte cytoplasm is filled with numerous ribosomes and mitochondria (Fig. 1F). In the cortical cytoplasm of the trophocytes there are numerous microfilaments (Fig. $1 \mathrm{H})$. The trophocyte membranes that directly communicate with the trophic core form long intertwined projections (Fig. 1E). Arrested oocytes have large spherical nuclei with single nucleoli (Fig. 1A, C, G). The cytoplasm of arrested oocytes contains fewer ribosomes (Fig. $1 \mathrm{G})$ than that of trophocytes (Fig. 1F).

The vitellaria of both species contain single developing oocytes (Fig. 1A, H) that are connected to the trophic core via broad nutritive cords (Fig. 1B, C, D). The nutritive cords are tightly packed with bundles of microtubules (not shown). The vitellarial oocyte is encompassed by a one-layered follicular epithelium (Fig. 1A, H). The follicular cells do not undergo diversification into distinct subpopulations (Fig. 1H).
TABLE 1. Number of germ cells recorded in 10 ovarioles of Ceroputo pilosellae and Puto superbus.

\begin{tabular}{lcccc}
\hline Species & Trophocytes & $\begin{array}{c}\text { Arrested } \\
\text { oocytes }\end{array}$ & $\begin{array}{c}\text { Developing } \\
\text { oocytes }\end{array}$ & Total \\
\hline \multirow{5}{*}{ Ceroputo } & 6 & 1 & 1 & 8 \\
pilosellae & 6 & 1 & 1 & 8 \\
& 6 & 2 & 1 & 10 \\
& 6 & 1 & 1 & 8 \\
& 7 & 1 & 1 & 8 \\
& 5 & 2 & 1 & 8 \\
& 6 & 1 & 1 & 8 \\
& 6 & 1 & 1 & 8 \\
& 27 & 2 & 1 & 8 \\
Puto & 13 & 2 & 1 & 8 \\
superbus & 25 & 4 & 1 & 30 \\
& 22 & 4 & 1 & 27 \\
& 27 & 4 & 1 & 32 \\
& 22 & 3 & 1 & 26 \\
& 25 & 4 & 1 & 30 \\
& 30 & 3 & 1 & 29 \\
& 43 & 7 & 1 & 35 \\
& 6 & 1 & 51 \\
\hline
\end{tabular}

In both species the constriction between the tropharium and vitellarium is surrounded by giant cells (termed bacteriocytes) that harbor endosymbiotic bacteria (Fig. 1D, $\mathrm{H})$.

\section{DISCUSSION}

\section{Morphology of ovaries}

Results of previous (Węglarska, 1961; Bielenin, 1962; Książkiewicz, 1980; Szklarzewicz \& Biliński, 1995; Szklarzewicz, 1998a, b, c; Szklarzewicz et al., 2002, 2005, 2010, 2013; Koteja et al., 2003; Ramirez-Cruz et

TABLE 2. Number of germ cells recorded in 10 ovarioles of representatives of the scale insect families studied.

\begin{tabular}{|c|c|c|c|c|c|}
\hline Family & Species & Trophocytes & Oocytes & Total & Source \\
\hline \multicolumn{6}{|c|}{ ARCHAEOCOCCOIDEA } \\
\hline Marchalinidae & Marchalina hellenica (Gennadius, 1883) & $23-30$ & $0-2$ & $25-32$ & Szklarzewicz et al., 2013 \\
\hline Margarodidae & Porphyrophora polonica (Linnaeus, 1758) & $7-14$ & $4-6$ & $12-19$ & Szklarzewicz, $1998 \mathrm{c}$ \\
\hline Monophlebidae & Palaeococcus fuscipennis (Burmeister, 1835) & 7 & 1 & 8 & Szklarzewicz et al., 2005 \\
\hline Ortheziidae & Newsteadia floccosa (De Geer, 1778) & $17-29$ & $12-29$ & $29-58$ & Szklarzewicz, 1997 \\
\hline Putoidae & $\begin{array}{l}\text { Puto albicans McKenzie, } 1967 \\
\text { Puto superbus (Leonardi, 1907) }\end{array}$ & $\begin{array}{l}23-43 \\
13-43 \\
\end{array}$ & $\begin{array}{l}2-3 \\
3-8 \\
\end{array}$ & $\begin{array}{l}25-45 \\
16-51\end{array}$ & $\begin{array}{c}\text { Szklarzewicz et al., } 2010 \\
\text { this study }\end{array}$ \\
\hline Steingeliidae & Steingelia gorodetskia Nasonov, 1908 & $15-35$ & $3-6$ & $21-41$ & Koteja et al., 2003 \\
\hline \multicolumn{6}{|c|}{ NEOCOCCOIDEA } \\
\hline Coccidae & Parthenolecanium pomeranicum (Kawecki, 1954) & 3 & 1 & 4 & Bielenin, 1962 \\
\hline Dactylopiidae & Dactylopius coccus Costa, 1829 & $6-7$ & 2 & $8-9$ & Ramirez-Cruz et al., 2008 \\
\hline Diaspididae & Diaspidiotus ostreaeformis (Curtis, 1843) & 3 & 1 & 4 & Węglarska, 1961 \\
\hline Eriococcidae & $\begin{array}{c}\text { Eriococcus spurius (Modeer, 1778) } \\
\text { Cryptococcus fagisuga Lindinger, } 1936\end{array}$ & $\begin{array}{c}3-7 \\
3\end{array}$ & $\begin{array}{c}1-4 \\
1 \\
\end{array}$ & $\begin{array}{c}4-11 \\
4\end{array}$ & $\begin{array}{l}\text { Szklarzewicz, } 1998 \mathrm{~b} \\
\text { Szklarzewicz, 1998b }\end{array}$ \\
\hline Kermesidae & Kermes quercus (Linnaeus, 1758) & $6-14$ & $2-6$ & $8-20$ & Szklarzewicz, 1998b \\
\hline Pseudococcidae & $\begin{array}{l}\text { Trionymus newsteadi (Green, 1917) } \\
\text { Ceroputo pilosellae (Sulc, 1898) }\end{array}$ & $\begin{array}{c}7 \\
5-7\end{array}$ & $\begin{array}{c}1 \\
1-3\end{array}$ & $\begin{array}{c}8 \\
8-10\end{array}$ & $\begin{array}{l}\text { Szklarzewicz, } 1998 \mathrm{~b} \\
\text { this study }\end{array}$ \\
\hline
\end{tabular}




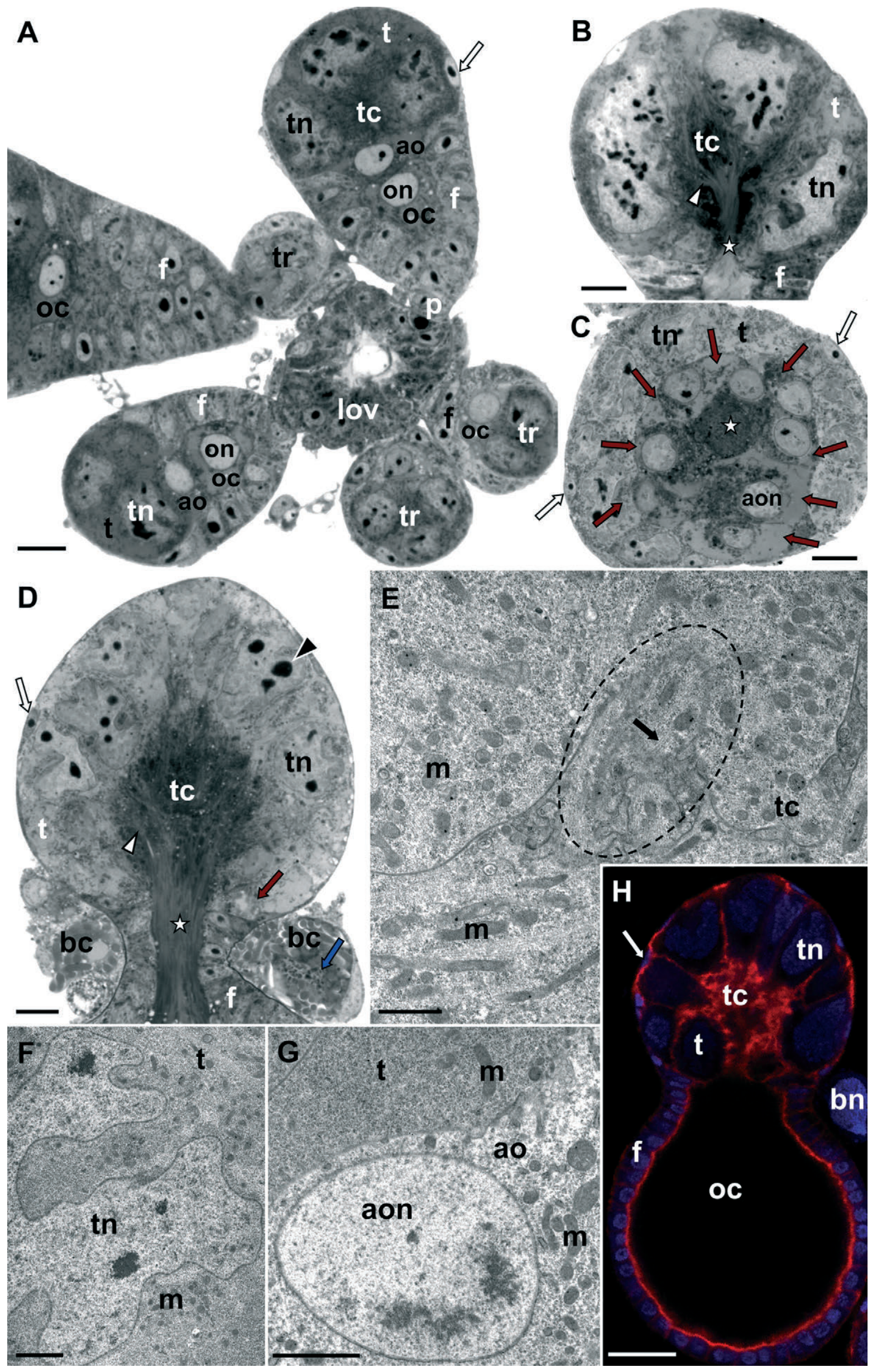


al., 2008) and present studies on the ovaries of scale insects have revealed that they exhibit several synapomorphic features (see Introduction), which strongly support the monophyly of this group (e.g. Koteja, 1974, 1996; Danzig, 1986; Foldi, 1997; Cook et al., 2002).

The ovaries of scale insects are composed of telotrophic ovarioles that as a rule develop asynchronously. As a consequence, the ovary of an adult female consists of ovarioles in different stages of development (see Fig. 1A). According to Koteja et al. (2003), asynchronous development of ovarioles may result in a prolonged oviposition period.

In spite of the several synapomorphic characters mentioned in the Introduction, there are however, significant differences in the number of germ cells in the ovarioles of primitive versus advanced scale insects (see Introduction). The analysis of serial sections has shown that tropharia of Puto superbus enclose many more germ cells (i.e. as a rule about 30) than tropharia of Ceroputo pilosellae (i.e. 7-9) (see Table 1). Since in ovarioles of both $P$. superbus and C. pilosellae only one oocyte develops, the total number of germ cells per ovariole in $P$. superbus is much greater than in $C$. pilosellae. As a rule, ovarioles of $C$. pilosellae are composed of 8 germ cells, i.e. they conform to the $\mathrm{N}=2^{\mathrm{n}}$ rule (where ' $\mathrm{N}$ ' is the number of cystocytes and ' $\mathrm{n}$ ' the number of divisions of the initial cystoblast). This suggests that clusters of germ cells in the ovarioles of $C$. pilosellae arise as a result of three synchronous divisions of the initial cystoblast. The 10-cell cluster in one of 10 ovarioles of $C$. pilosellae analyzed was formed as a result of three synchronous divisions and one additional one of two cystocytes. In $P$. superbus, clusters arise as a result of at least 4 divisions (7 out of 10 ovarioles analyzed were composed of less than 32 germ cells and 3 were composed of 32 or more germ cells), but as a rule the number of germ cells per ovariole does not conform to the $\mathrm{N}=2^{\mathrm{n}}$ rule.

Reports on the formation of clusters of germ cells in scale insects are very rare. The first description of this stage of ovary development in the Diaspididae was provided by Węglarska (1961). Szklarzewicz observed development of clusters of cystocytes in the Ortheziidae (1997), Pseudococcidae (1998b), Eriococcidae (1998b) and Margarodidae (1998c). All of these studies indicate that the formation of clusters of germ cells in scale insects is similar to that in other insects with meroistic ovarioles (reviewed in King, 1970; Telfer, 1975; King \& Büning, 1985). Initially as a result of incomplete mitotic divisions the cystocytes remain interconnected by intercellular bridges that are filled by electron-dense, amorphous fusomal material (= fusome). Then, the fusomes in all the intercellular bridges coalesce forming a polyfusome and as a consequence the cystocytes become arranged in the form of a rosette, which subsequently elongates forming an ovariole.

As in other scale insects, the tropharia of both the species examined consist of individual trophocytes with large and lobated nuclei with several prominent nucleoli (see Szklarzewicz, 1998a for further details). It is generally known that trophocyte nuclei with this type of structure have a particular function, i.e. synthesis of RNA. On the other hand, the presence of microfilaments in the cytoplasm of trophocytes and trophic core as well as microtubules in trophocyte processes, nutritive cords and trophic core is associated with the transportation of macromolecules (e.g. ribonucleoproteins) and organelles (e.g. mitochondria) from trophocytes to the developing oocyte (Gutzeit, 1986; Münz \& Dittman, 1987; Szklarzewicz \& Biliński, 1995; Szklarzewicz et al., 2002).

Our studies have revealed that in the tropharia of both the species examined arrested oocytes are present. This finding is of special interest, because arrested oocytes have not been reported in other representatives of the family Pseudococcidae (Büning, 1994; Szklarzewicz, 1998b). Since we did not observe more than one oocyte in the vitellarium of an ovariole, it is not known whether the arrested oocytes in $C$. pilosellae and P. superbus are capable of further development. The large size of these cells and ultrastructure of their cytoplasm seem to indicate that they may indeed develop. It should be noted that the occurrence of arrested oocytes capable of further development is typical of archaeococcoids as well as

Fig. 1. Organization of the female reproductive system in Ceroputo pilosellae and Puto superbus. A - Ceroputo pilosellae. Cross section of an ovary. Ovarioles are arranged around the distal part of the lateral oviduct; ao - arrested oocyte, $f$ - follicular epithelium, lov - lateral oviduct, oc - oocyte, on - oocyte nucleus, $\mathrm{p}$ - pedicel, $\mathrm{t}$ - trophocyte, tc - trophic core, tn - trophocyte nucleus, $\operatorname{tr}$ - tropharium, white arrow - cell of an inner epithelial sheath. Methylene blue, scale bar $-10 \mu \mathrm{m}$. B - Ceroputo pilosellae. Longitudinal section through tropharium; $\mathrm{f}-$ follicular epithelium, $\mathrm{t}$ - trophocyte, $\mathrm{tc}-$ trophic core, tn - trophocyte nucleus, asterisk - nutritive cord, white arrowhead - cytoplasmic process joining trophocyte with the trophic core. Methylene blue, scale bar $-10 \mu \mathrm{m}$. C - Puto superbus. Cross section through the proximal region of tropharium; aon - nucleus of arrested oocyte, $\mathrm{t}-$ trophocyte, tn - trophocyte nucleus, asterisk - nutritive cord, white arrow - cell of inner epithelial sheath, red arrow - arrested oocyte. Methylene blue, scale bar - $10 \mu \mathrm{m}$. D - Puto superbus. Longitudinal section through tropharium. In the close neighborhood of the ovariole there are bacteriocytes with endosymbiotic bacteria (bc); $\mathrm{f}$ - follicular epithelium $\mathrm{t}$ - trophocyte, tc - trophic core, tn - trophocyte nucleus, asterisk - nutritive cord, white arrow - cell of inner epithelial sheath, black arrowhead - trophocyte nucleolus, white arrowhead - cytoplasmic process joining trophocyte with trophic core, red arrow - arrested oocyte. Methylene blue, scale bar $-10 \mu \mathrm{m}$. E - Ceroputo pilosellae. Fragment of a trophic core; $\mathrm{m}$ - mitochondrium, tc - trophic core, black arrow - microtubules, encircled - intertwined projections of trophocyte membranes. TEM, scale bar $-2 \mu \mathrm{m}$. F - Ceroputo pilosellae. Fragment of nucleus and cytoplasm of a trophocyte; $\mathrm{m}$ - mitochondria, $\mathrm{t}$ - trophocyte, $\mathrm{tn}$ - trophocyte nucleus. TEM, scale bar $-2 \mu \mathrm{m}$. $\mathrm{G}-$ Ceroputo pilosellae. Fragment of a trophocyte and arrested oocyte; ao - arrested oocyte, aon - arrested oocyte nucleus, $\mathrm{m}-$ mitochondrium, $\mathrm{t}$ - trophocyte. TEM, scale bar $-2 \mu \mathrm{m}$. H - Puto superbus. Longitudinal section through a young ovariole; bn - bacteriocyte nucleus, $\mathrm{f}$ - follicular epithelium, oc - oocyte, $\mathrm{t}$ - trophocyte, $\mathrm{tc}$ - trophic core, $\mathrm{tn}$ - trophocyte nucleus, white arrow - cell of inner epithelial sheath. DAPI + rhodamine-phalloidin, confocal microscope, scale bar $-10 \mu \mathrm{m}$. 
aphids (Szklarzewicz \& Biliński, 1995; Szklarzewicz, 1997, 1998c; Szklarzewicz et al., 2000, 2002, 2009, 2010, 2013; Koteja et al., 2003). Within neococcoids arrested oocytes are only present in some representatives of two families (Eriococcidae and Kermesidae) (Szklarzewicz, 1998b). According to Szklarzewicz (1998b), arrested oocytes in neococcoids do not develop but degenerate even in the tropharium. On the basis of the above observations, Szklarzewicz (1998b) suggested that the occurrence of arrested oocytes in aphids, archaeococcoids and some neococcoids represents a symplesiomorphy, while their tendency to degenerate and absence in neococcoids may be regarded as an autapomorphic character of this group.

\section{Phylogenetic and taxonomic conclusions}

The analysis of serial sections of 10 ovarioles of each species has revealed that ovarioles of $P$. suberbus are composed of many more germ cells than those of $C$. pilosellae (i.e. $8-10$ in $C$. pilosellae, $16-51$ in $P$. superbus). Moreover, these results indicate that the number of germ cells in ovarioles of $P$. superbus is similar (or even higher) to that found in ovarioles of representatives of archaeococcoid families of scale insects so far investigated, i.e. 29-58 in Newsteadia floccosa (Ortheziidae), 12-19 in Porphyrophora polonica (Margarodidae s. str.), 21-41 in Steingelia gorodetskia (Steingeliidae), 25-45 in Puto albicans (Putoidae) and 25-32 in Marchalina hellenica (Marchalinidae) (see Table 2) (Szklarzewicz \& Biliński, 1995; Szklarzewicz, 1997, 1998c; Koteja et al., 2003; Szklarzewicz et al., 2010, 2013). On the other hand, the number of germ cells per ovariole in $C$. pilosellae is comparable with that described for representatives of neococcoid families, i.e. 8-20 in Kermes quercus (Kermesidae), 4-11 in Eriococcus spurius (Eriococcidae), 8-9 in Dactylopius coccus (Dactylopiidae), 8 in Trionymus newsteadi (Pseudococcidae) and 4 in Cryptococcus fagisuga (Eriococcidae), Parthenolecanium pomeranicum (Coccidae) and Diaspidiotus ostreaeformis (Diaspididae) (see Table 2) (Węglarska, 1961; Bielenin, 1962; Szklarzewicz, 1998b; RamirezCruz et al., 2008). Thus, the differences in the ovariole organization in $P$. superbus and $C$. pilosellae confirm the view that these species are phylogenetically distant (Williams et al., 2011).

It should be noted that within the family Pseudococcocidae only ovaries of representatives of the subfamily Pseudococcinae have been examined so far (Büning, 1994; Szklarzewicz, 1998b). The ovarioles of all the pseudococcids examined contained a relatively low and constant number of germ cells, i.e. 8 ( 7 trophocytes +1 developing oocyte). Results of our studies on ovaries of members of the subfamily Phenacoccinae, $C$. pilosellae (this study) and Phenacoccus aceris (unpublished data), indicate that they, as a rule, have also only 8 germ cells (only one of 10 ovarioles of $C$. pilosellae examined contained 10 germ cells). The ovarioles of Pseudococcinae and Phenacoccinae, however, differ significantly in terms of the presence of arrested oocytes. Such oocytes occur commonly in both species of the Phenacoccinae exam- ined but have never been reported in the Pseudococcinae. In the light of above observations it is possible that ovaries of pseudococcids are more diversified than previously supposed. Thus, to elucidate the evolutionary trends in the ovaries of the Pseudococcidae further studies are required.

Puto was placed in the Pseudococcidae for many years, but species of this genus possess some features that are distinct from those of pseudococcids: usually three or sometimes four campaniform sensilla on ventral and dorsal surface of each trochanter (in almost all Pseudococcidae there are two sensilla of this type ) and general occurrence of a pair of spurs at the base of the claw, named basal spurs (apparently unique to Puto) (in adult females), seven segmented antennae in first-instar of most species (in pseudococcids there are at most six antennal segments in the first larval stage) and adult males have a row of unicorneal eyes encircling the head and a pair of ocelli (males of pseudococcids possess only dorsal and ventral pairs of unicorneal eyes and a pair of ocelli) (Williams et al., 2011). Taking into consideration the occurrence of these features it seems that Puto should be placed in a separate family the Putoidae. Representatives of Putoidae possess an $\mathrm{XX}-\mathrm{XO}$ sex chromosome system, which is a feature they share with archaeocoocoids (Hughes-Schrader, 1944; Gavrilov, 2007). The males of species of Puto do not have compound eyes (which is characteristic for most archaeococcoids males) and compound eyes have degenerated in some specialized groups of archaeococcoids: Steingeliidae, Phenacoleachiidae, Grimaldiellidae and Albicoccidae (the last two are fossil groups) (Koteja, 2000, 2004). Abdominal spiracles are present in representatives of extant archaeococcoids and absent in neococcoids (see Introduction) and Putoidae do not have such structures. In all representatives of fossil archaeococcoid families abdominal spiracles have not been detected (because of the state of preservation of the material). The results of molecular analysis (Gullan \& Cook, 2007) and morphological studies on the ovaries (Szklarzewicz et al., 2010) indicate that Putoidae should be placed within the archaeococcoids.

Ceroputo pilosellae was classified as Puto pilosellae by many workers (e.g. Tereznikova, 1975; Kosztarab \& Kozár, 1988; Danzig, 1999). In fact this species shares features with the Phenacoccinae: only two campaniform sensilla on ventral and dorsal surface of each trochanter and claw lacking basal denticles (adult females), six segmented antennae in first-instar nymph and only a pair of dorsal and pair of ventral simple eyes plus a pair of lateral ocelli in adult males (Hardy et al., 2008). According to Hardy et al. (2008) Ceroputo pilosellae should be placed in the subfamily Phenacoccinae within the neococcoid family Pseudococcidae.

Taking into consideration all the features discussed above and the results obtained, we strongly support earlier suggestions (Hodgson, 2002; Gullan \& Cook, 2007; Hardy et al., 2008; Williams et al., 2011) that: (1) the genera Puto and Ceroputo should not be synonymized; (2) species Macrocerococcus superbus should be placed 
in the genus Puto; (3) genus Puto should belong to its own family the Putoidae within the archaeococcoid scale insects; (4) the species Ceroputo pilosellae should belong to the family Pseudococcidae (subfamily Phenacoccinae).

ACKNOWLEDGEMENTS. We are deeply indebted to $\mathrm{J}$. Kubrakiewicz (University of Wrocław) for providing the specimens of Puto superbus and to A. Jankowska, W. Krzeptowski, D. Semik and B. Szymańska for their skilled technical assistance. This work was supported by research grant K/ZDS/ 001962.

\section{REFERENCES}

Beardsley J.W. 1969: A new fossil scale insect (Homoptera: Coccoidea) from Canadian amber. — Psyche 76: 270-279.

BIELENIN I. 1962: Anatomical and histochemical investigations on the genus Lecanium Burm. Part. I. Female reproductive organs of Lecanium pomeranicum Kaw. (Homoptera, Coccoidea). - Acta Biol. Crac. (Zool.) 5: 9-25.

BILIŃsKI S. 1998: Introductory remarks. - Folia Histochem. Cytobiol. 3: 143-145.

BilińSKi S.M., KsiążKIEWicz-KapRalsKa M. \& ŠTYs P. 1990: Unusual organization of the tropharium in the telotrophic ovarioles of an insect, Saldula saltatoria. - Tissue Cell 22 213-219.

BorCHSENIUS N.S. 1949: Insects: Homoptera; suborders mealybugs and scales (Coccoidea). Family mealybugs (Pseudococcidae). Vol. VII. In: Fauna SSSR 38. N.S. Zool. Institut Akad. Nauk SSSR, Moscow, Leningrad, 382 pp. [in Russian].

BoRCHSENIUS N.S. 1958: On the evolution and phylogenic interrelations of Coccoidea (Insecta: Homoptera). - Zool. Zh. 37: 765-780.

BüNING J. 1985: Morphology, ultrastructure and germ cell cluster formation in ovarioles of aphids. $-J$. Morphol. 186: 209-221.

BünIng J. (ed.) 1994: The Insect Ovary: Ultrastructure, Previtellogenic Growth and Evolution. 1st ed. Chapman and Hall, London, $400 \mathrm{pp}$.

Cook L.G., Gullan P.J. \& Trueman H.E. 2002: A preliminary phylogeny of the scale insects (Hemiptera: Sternorrhyncha: Coccoidea) based on nuclear small-subunit ribosomal DNA. - Mol. Phyl. Evol. 25: 43-52.

DanzIg E.M. 1986: Coccids of the Far-Eastern USSR (Homoptera: Coccinea). Phylogenetic Analysis of Coccids in the World Fauna. Amerind, New Delhi, 450 pp.

Danzig E.M. 1999: Mealybugs of the genus Puto Signoret (Homoptera, Pseudococcidae) from Russia and adjacent countries. - Entomol. Obozr. 78: 79-91.

Ferris G.F. 1918: The California Species of Mealy Bugs. Stanford University Publications, University Series. Palo Alto, 78 pp.

FoLDI I. 1997: Defense strategies in scale insects: Phylogenetic inference and evolutionary scenarios (Hemiptera, Coccoidea). In Grandcolas P. (ed.): The Origin and Biodiversity in Insects: Phylogenetic Tests of Evolutionary Scenarios. Memoires du Museum National d'Histoire Narurelle 173, Paris, pp. 203-230.

GaVRILOV I.A. 2007: A catalog of chromosome numbers and genetic systems of scale insects (Homoptera: Coccinea) of the world. - Israel J. Entomol. 37: 1-45.

Gavrilov-Zimin I.A. \& Danzig E.M. 2012: Taxonomic position of the genus Puto Signoret (Homoptera: Coccinea: Pseudococcidae) and separation of higher taxa in Coccinea. - Zoosyst. Rossica 21: 97-111.
Gullan P.J. \& CoOK L.G. 2007: Phylogeny and higher classification of the scale insects (Hemiptera: Sternorrhyncha: Coccoidea). - Zootaxa 1668: 413-425.

GUllan P.J. \& MARTIN J.H. 2009: Sternorrhyncha (jumping plant-lice, whiteflies, aphids, and scale insects). In Resh V.H. \& Cardé R.T. (eds): Encyclopedia of Insects. Elsevier, San Diego, pp. 957-967.

GutZerT H.O. 1986: The role of microfilaments in cytoplasmic streaming in Drosophila follicles. - J. Cell Sci. 80: 159-169.

Hardy N.B., Gullan P.J. \& Hodgson C.J. 2008: A subfamilylevel classification of mealybugs (Hemiptera: Pseudococcidae) based on integrated molecular and morphological data. - Syst. Entomol. 33: 51-71.

Hodgson C.J. 2002: Preliminary phylogeny of some non margarodidae Coccoidea (Hemiptera) based on adult male characters. - Boll. Zool. Agraria Bachicolt. 33: 129-137.

HuEBNER E. 1981: Nurse cells-oocyte interaction in the telotrophic ovary of an insect, Rhodnius prolixus. - Tissue Cell 13: $105-125$.

HugHES-SCHRADER S. 1944: A primitive coccid chromosome cycle in Puto sp. - Biol. Bull. 87: 167-176.

JURA C. 1958: The early developmental stages of ovoviviparous scale insects Quadraspidiotus ostreaeformis (Curt.) (Homoptera, Coccidae, Aspidiotini). — Zool. Polon . 9: 17-34.

KING R.C. 1970: Ovarian development in Drosophila melanogaster. Academic Press, New York, $\mathrm{x}+227 \mathrm{pp}$.

KING R.C. \& BüNING J. 1985: The origin and functioning of insect oocytes and nurse cell. In Kerkut G.A. \& Gilbert L.I. (eds): Comprehensive Insect Physiology, Biochemistry and Pharmacology. Vol. 1. Pergamon Press, Oxford, pp. 37-82.

Kondo T., Gullan P.J. \& Williams D.J. 2008: Coccidology. Rev. Corp. Ciencia Tecn. Agrop. 9: 55-61.

Kosztarab M. \& KozÁr F. 1988: Scale Insects of Central Europe. Akadémiai Kiadó, Budapest, 456 pp.

Kотеја J. 1974: On the phylogeny and classification of the scale insects (Homoptera, Coccinea) (discussion based on the morphology of the mouthparts). - Acta Zool. Crac. 19: 267-326.

Koteja J. 1996: Scale insects (Homoptera: Coccinea) a day after. In Schaefer C.W. (ed.): Studies of Hemipteran Phylogeny. Proceedings of Thomas Say Publications in Entomology. Entomological Society of America, Lanham, MD, pp. 65-88.

Koteja J. 2000: Scale insects (Homoptera, Coccinea) from Upper Cretaceous New Jersey amber. In Grimaldi D. (ed.): Studies on Fossils in Amber, with Particular Reference to the Cretaceous of New Jersey. Backhuys Publishers, Leiden, pp. 147-229.

Koteja J. 2004: Scale insects (Hemiptera: Coccinea) from Cretaceous Myanmar (Burmese) amber. - J. Syst. Palaeontol. 2: $109-114$.

Kотеja J. 2008: Xylococcidae and related groups (Hemiptera: Coccinea) from Baltic amber. - Prace Muz. Ziemi 49: $19-56$.

Koteja J. \& Azar D. 2008: Scale insects from Lower Cretaceous amber of Lebanon (Hemiptera: Sternorrhyncha: Coccinea). - Alavesia 2: 133-167.

Koteja J. \& Poinar O. 2001: A new family, genus and species of scale insect (Hemiptera: Coccinea: Kukaspididae, new family) from Cretaceous Alaskan amber. - Proc. Entomol. Soc. Wash. 103: 356-363.

Koteja J., Pyka-Fosciak G., Vogelgesang M. \& Szklarzewicz T. 2003: Structure of the ovary in Steingelia (Sternorrhyncha: Coccinea), and its phylogenetic implications. - Arthr. Struct. Dev. 32: 247-256. 
KstążKIEWICZ M. 1980: Ultrastructure of the trophic chamber and nutritive cord of Aspidiotus hederae (Homoptera, Coccoidea). - Cell Tiss. Res. 213: 149-157.

KsIążKIEWICZ-KAPRALSKA M. 1985: Organization of the trophic chamber of homopteran insects. I. Cercopidae: Cicadomorpha. - Cytobios 42: 133-145.

LEONARDI G. 1907: Contribuzione alla conoscenza delle cocciniglie Italiane. - Boll. Lab. Zool. Gen. Agraria R. Scuola Superior Agricolt. 1: 135-169.

LINDINGER L. 1912: Die Schildläuse (Coccidae) Europas, Nordafrikas und Vorder-Asiens, einschliesslich der Azoren, der Kanaren und Madeiras. Ulmer, Stuttgart, 388 pp.

Magakyan Y.A., Makaryan S.R., Pterossyan A.V., Mktchyan L.P., Abroyan L.O. \& Hakopyan L.A. 1975: The oogenesis of the Ararat cochineal (Porphyrophora hamelli Brandt). I. Histomorphological characteristics of the formation of follicular apparatus and the development of oocytes. Cytologia 18: 932-936 [in Russian].

Marotta S. \& Tranfaglia A. 1993: Le specie del genere PutoSignoret (Homoptera: Coccoidea: Pseudococcidae) dell'Europa centrale e del bacino del Mediterraneo. - Boll. Lab. Entomol. Agraria 'Filippo Silvestri' 48: 171-205.

Münz A. \& DitTMan F. 1987: Voltage gradients and microtubules both involved in intercellular protein and mitochondria transport in the telotrophic ovariole of Dysdercus intermedius. — Rouxs Arch. Dev. Biol. 196: 391-396.

NiżNIK S. \& SZKLARZEWICZ T. 2007: Structure and development of hermaphroditic gonad in Icerya purchasi (Insecta, Hemiptera, Coccinea: Monophlebidae). - Zool. Polon. 52: 71-90.

Ramírez-Cruz A., Llanderal-Cázares C. \& Racotta R. 2008: Ovariole structure of the cochineal scale insect, Dactylopius coccus. - J. Insect Sci. 8: 20, available online: insectscience.org/8:20, 5 pp.

Simczyjew B., OgorzaleK A. \& Štys P. 1998: Heteropteran ovaries: variations on the theme. - Folia Histochem. Cytobiol. 36: $147-156$.

ŠTYS P., BüNING J. \& BILINSKI S.M. 1998: Organization of the tropharia in the telotrophic ovaries of the dipsocomorphan bugs, Cryptostemma alienum Herrich-Schaeffer and C. carpaticum Josifov (Heteroptera, Dipsocoromorpha). - Int. J. Insect Morphol. Embryol. 27: 129-133.

SzKLARZEWICZ T. 1997: Structure and development of the telotrophic ovariole in ensign scale insects (Hemiptera, Coccomorpha: Ortheziidae). — Tiss. Cell 29: 31-38.

SZKLARZEWICZ T. 1998a: The ovaries of scale insects (Hemiptera, Coccinea). Morphology and phylogenetic conclusions. Folia Histochem. Cytobiol. 36: 157-165.

SzKLARZEWICZ T. 1998b: Structure of the ovaries of scale insects. I. Pseudococcidae, Kermesidae, Eriococcidae and Cryptococ- cidae (Insecta, Hemiptera, Coccinea). — Int. J. Insect Morphol. Embryol. 27: 167-172.

SzKLARZEWICZ T. 1998c: Structure of the ovaries of scale insects. II. Margarodidae (Insecta, Hemiptera, Coccinea). - Int. J. Insect Morphol. Embryol. 27: 319-324.

SZKLARZEWICZ T. \& BILINSKI S.M. 1995: Structure of ovaries in ensign scale insects, the most primitive representatives of Coccomorpha (Insecta, Hemiptera). - J. Morphol. 224: 23-29.

Szklarzewicz T., WNęK A. \& BilińSKi S.M. 2000: Structure of ovarioles in Adelges laricis, representative of the primitive aphid Adelgidae. - Acta Zool. (Stockholm) 81: 307-313.

Szklarzewicz T., Vogelgesang M., Jagięa K. \& Oskwarek J. 2002: Cytoarchitecture of the ovarioles in scale insects (Hemiptera, Coccinea). - Folia Histochem. Cytobiol. 40: 227-228.

SzKLARZEWICZ T., KęDRA K. \& NiżNIK S. 2005: Ultrastructural studies of the ovary of Palaeococcus fuscipennis (Burmaister) (Insecta, Hemiptera, Coccinea: Monophlebidae). — Folia Biol. (Kraków) 53: 45-50.

Szklarzewicz T., Jankowska W., Wieczorek K. \& Wegierek P. 2009: Structure of the ovaries of the primitive aphids Phylloxera coccinea and Phylloxera glabra (Hemiptera, Aphidinea: Phylloxeridae). - Acta Zool. (Stockholm) 90: 123-131.

Szklarzewicz T., Michalik A., Czaja A. \& SzydŁowska S. 2010: Germ cell cluster formation and ovariole structure in Puto albicans and Crypticerya morrilli (Hemiptera: Coccinea). Phylogenetic implications. - Eur. J. Entomol. 107: 589-595.

Szklarzewicz T., Kalandyk-KolodziejczyK M., Kot M. \& Michalik A. 2013: Ovary structure and transovarial transmission of endosymbiotic microorganisms in Marchalina hellenica (Insecta, Hemiptera, Coccomorpha: Marchalinidae). Acta Zool. (Stockholm) 94: 184-192.

TELFER W.H. 1975: Development and physiology of the oocytenurse cell syncytium. - Adv. Insect Physiol. 11: 161-184.

Tereznikova E.M. 1975: Fauna of Ukraine. Vol. 20. Institut Zoologii, Akademiya Nauk Ukrainskoi RSR, Kiev, 296 pp. [in Ukrainian].

WĘGLARSKA B. 1961: Oogenesis in the ovoviviparous scale insect Quadraspidiotus ostreaeformis (Curt) (Homoptera, Coccidae: Aspidiotini). Part I. Morphological and cytological investigations. - Zool. Polon. 11: 267-298.

Williams D.J., Gullan P.J., Miller D.R., Matile-Ferrero D.R. $\&$ Han S.I. 2011: A study of the scale insect genera Puto Signoret (Hemiptera: Sternorrhyncha: Coccoidea: Putoidae) and Ceroputo Šulc (Pseudococcidae) with a comparison to Phenacoccus Cockerell (Pseudococcidae). - Zootaxa 2802: 1-22.

Received January 10, 2013; revised and accepted April 15, 2013 